\title{
PHYSICO- CHEMICAL STUDY OF RIVER PURNA IN DARYAPUR TAHASIL, DISTRICT: AMRAVATI (M.S)
}

\author{
J.R. Ingle, Bobdey A.D., Sawarkar B. W., Kutemate O. G., \\ Bhagat V.B. and Kutemate N. B. \\ SGB Amravati University Amravati \\ Shri Shivaji Science College, Congress Nagar, Nagpur-12 \\ drad.bobdey@sscn.in
}

\section{Abstract:}

In order to assess the quality of water in river Purna of Daryapur tahasil, the water was analysed for different physical and chemical parameters for a period of one year. Various physical and chemical parameter like temperature, conductivity, turbidity, $\mathrm{pH}$, Free $\mathrm{CO}_{2}$, total dissolved solids, total alkalinity, dissolved oxygen, biochemical oxygen demand were studied. The results reveal that seasonal variation and anthropogenic activities along the bank of river leads to changes in physico-chemical properties of water in river.

Keyw ords:-Physico chemical parameters, Purna river, Water Quality, DO, CO2, Chloride, Phosphates.

\section{Introduction:}

Water is called life; it is the key factor on which existence of life depend infact life has originated in water. Earth has many water sources covering about $70 \%$ of the planet. The percentage of water is more but availability of water is less as only little water is fresh and maximum water is saline. The amount of water that can be used to satisfy human need is very little so water must be used courteously. There is no end of mans greed of using water as water is free of charge. Every activity for which water is used pollutes water. The growing population, rapidly growing industries, different agricultural activities, faster growing infrastructural activities are some reasons that pollute water. Pollution of fresh water bodies is a matter of serious concern throughout the world. It is the need of the hour to think about water pollution and to control pollution using proper scientific study of water bodies.

In India the physic - chemical characteristics of river water have been studied by many researchers and workers Singh Namarata 2010, Sharma Shraddhaet.al, 2011, Sujithia P.C 2012 and others. The present investigation involves the analysis of physico - chemical parameters of river Purna in Daryapur tahasil. River Purna is source of drinking water and irrigation for nearby villages.

\section{Material and Methods:}

Water samples were collected for physicochemical analysis from three sampling sites along river Purna, site-1 Nanded Bujuruk village site-2 Amla village, site-3 Shirajda village in Daryapur tahasil. Some of water characteristics viz. Temperature, $\mathrm{pH}$ were determined at the sampling station with the help of portable water analysis kit and others were mostly tested within 24 hours of collection. The determination of physico-chemical properties were done by Standard methods for the examination of water and wastewater analysis (APHA, 1975). Preservation of water samples whenever necessary was done at $4^{\circ} \mathrm{C}$. Water was collected in polythene bottle of 1 litre size and the instruments were use of accuracy and chemical used were of A.R Grade.

\section{Result and Discussion:}

The physico-chemical characteristics of all samples are in the form of temperature, Total hardness, Alkalinity, Chloride content, TDS, ph, Free $\mathrm{CO} 2, \mathrm{BOD}$ and $\mathrm{DO}$. It has been found that parameters for all studying stations of Purna are in the limit but less amount of dissolved oxygen was observed at different stations. The water samples were collected for a period of one year (June2015 to May2016). The results of the seasonal variation in the physicochemical parameters of Purna River are summarized in table 1.

Temperature- The temperature at all sites of Purna river ranged between $24.7{ }^{\circ} \mathrm{C}$ to $25.1^{\circ} \mathrm{C}$. The variation is mainly related with the temperature of atmospheric and weather condition. The temperature fluctuation of water sample usually depends on the season, sampling time, as well as the temperature of the effluents pouring into the river (Jayaraman et al., 2003).

Total Hardness- A range between 68.2 to 72.7 $\mathrm{mg} / 1$ was observed in Purna river. The variation in hardness is observed probably due to regular addition of large quantities of sewage, detergents and large scale human use or due to utilization 
of carbonate and bicarbonates by aquatic plants. Although hard water has no known effect on health but is unsuitable for domestic uses (Wolf et al, 2013). Water of Purna river is suitable for domestic and drinking purposes due less hardness.

Alkalinity- Alkalinity of purna ranges from 176 $\mathrm{mg} / 1$ to $182 \mathrm{mg} / 1$. Increase in alkalinity may be due to increase in of organic matter, sewage and localized use of detergents (Mitchell and Marshall, 1973).More washing activity is observed at site- 3 hence maximum alkalinity is observed at this sight.

Chloride content- The chloride content of water ranges from $8.4 \mathrm{mg} / 1$ to $9.1 \mathrm{mg} / 1$ in Purna water of Daryapur Tahasil. Increase percentage of chloride was probably due to amount of sewage discharge in the river, similar observation has been made by Khanna and Bhutani (2003).

Total Dissolved Solid- TDS of Purna river ranged between 7.34 to 7.52 . The rise of $\mathrm{pH}$ is due to cloth washing, discharge of domestic waste in river Purna. Similar finding is also observed by Pankaj Kumar et.al (2015) in river Varuna.

Free $\mathbf{C O}_{2}$ - The amount of $\mathrm{CO}_{2}$ increases from site-1 to site-3 in Purna river. Hosetti et.al (1994), have reported minimum values at upstream station and maximum at downstream station due to discharge of stream of city sewage, in river Panchaganga at Kolhapur (M.S.). The range of $\mathrm{CO}_{2}$ in river is between 3.54 $\mathrm{mg} / 1$ to $4.16 \mathrm{mg} / 1$.
Biochemical Oxygen Demand- The BOD values in Purna ranges between $4.3 \mathrm{mg} / 1$ to $4.9 \mathrm{mg} / 1$. The biochemical oxygen demand also indicates the amount of organic compounds in water as measured by the volume of oxygen required by the bacteria to metabolize it under aerobic condition. For more organic matter, more oxygen is required by bacteria for its decomposition. This results in release of organic nutrients in water bodies resulting in death of organisms thriving on water (Jonasson et al., 2012).

Dissolved Oxygen- The DO values varied according to the rate of respiration and decomposition of organic materials in the water. Pollution process tends to deplete the DO in the water Mason (1989). The DO values in Purna were observed between $7.6 \mathrm{mg} / 1$ to $8.1 \mathrm{mg} / 1$. The DO and BOD values show a inverse relation with each other.

Phosphates- The value of phosphate in Purna ranged between $0.27 \mathrm{mg} / 1$ to $0.32 \mathrm{mg} / 1$. The domestic activities of the population near by the bank of river results in to increase in the percentage of phosphates in water. In river basin farming and use of cow dung as manure by farmers during summer season pollute the river and constitute the major source of phosphate in river water at station S-3. Mukharjee et.al, (1994), Agrawal and Kannan, (1996) in river Mandakini have described that, the detergents increase the phosphate load in the fresh water bodies.

Table - 1 Average results of physic - chemical parameters of Purna river of Daryapur Tahasil.

\begin{tabular}{|c|c|c|c|c|}
\hline \multirow[t]{2}{*}{ Sr.No } & \multirow[t]{2}{*}{ Parameter } & \multicolumn{3}{|c|}{ Sampling points in Purna river } \\
\hline & & Site-1 & Site-2 & Site-3 \\
\hline 1 & Temperature in ${ }^{\circ} \mathrm{C}$ & 24.7 & 24.98 & 25.1 \\
\hline 2 & Total Hardness in $\mathrm{mg} / 1$ & 68.2 & 72.7 & 71.9 \\
\hline 3 & Alkalinity in $\mathrm{mg} / 1$ & 176 & 179 & 182 \\
\hline 4 & Chloride content in $\mathrm{mg} / 1$ & 8.4 & 8.7 & 9.1 \\
\hline 5 & TDS in $\mathrm{mg} / 1$ & 147 & 149 & 156 \\
\hline 6 & $\mathrm{Ph}$ & 7.34 & 7.52 & 7.48 \\
\hline 7 & Free $\mathrm{CO}_{2}$ in $\mathrm{mg} / 1$ & 3.54 & 3.98 & 4.16 \\
\hline 8 & $\mathrm{BOD}$ in $\mathrm{mg} / 1$ & 4.5 & 4.9 & 4.3 \\
\hline 9 & DO in $\mathrm{mg} / 1$ & 7.9 & 7.6 & 8.1 \\
\hline 10 & Phosphate in $\mathrm{mg} / 1$ & 0.27 & 0.29 & 0.32 \\
\hline
\end{tabular}

\section{References:}

Agrawal G. D. and Kannan G. K., (1996). Degradetion of river due to diffuse activities and apropriate approach for management- A case study of river Mandakini. IAEM. Vol. 23, 113-121.

Hosetti B. B., Kulkarni A. R. and Patil H. S. (1994).Water quality in Jayanthi Nalla and

Panchganga at Kolhapur. Indian J. Environ. Hlth., Vol. 36, No. 2, 124-127.
Jayaraman, P.R., Ganga, D.T., Vasudevan, N.T., (2003). Water Quality Studies on Karamana River, Thiruvananthapuram District, South Kerala, India. Poll. Res. 22(1), 89-100.

Jonasson L, Hansen JLS, Wan Z, She J. (2012). The impacts of physical processes on oxygen variations in the North Sea-Baltic Sea transition zone. Ocean Sci. 8: $37-48$. 
Khanna, D.R. ad Bhutani, Rakesh (2003) Limnological status of Sati kund pond Haridwar. Ind. J. Environ. Sci. 7 (2): 131-136.

Mason C.F. (1989), Biology of fresh water pollution. Longman Scientific and Tech. Publ. Essex, U.K.

Mitchell D. S. and Marshall B. E. (1973). Hydrobiological observation of 3 rhodegian reservoirs. Fresh water biol., 1974 (4): 61-72.

Mukherjee B., Pankajakshi G. V. N., Bose P., Kumar R., Kumar P., Kumar D., Kumar A., Kumari R., Singh S. and Kanogia S. (1994). The phosphate load from detergent inputs and its effect in fresh waters. J. Environ. Biol., 15 (1) : 27-39.

Pankaj Kumar, Singh, A.N., Shrivastava, R., Mohan,D., (2015). Assessment of seasonal variation in water quality dynamics in River Varuna- A major Tributary of River Ganga. Int. J. Adv. Res. 3(3), 11761193.
Sharma Shraddha, Vishwakarma Rakesh, Dixit Savita and Jain Praveen (2011) Evaluation of Water Quality of Narmada River with reference to Physcochemical Parameters at Hoshangabad city, MP, India, Res.J.Chem.Sci1(3):40-48.

Singh Namrata (2010) Physicochemical properties of polluted water of river Ganga at Varanasi, International Journal of Energy and Environment (IJEE), 1( 5):823-832.

Sujitha P.C. Mitra Dev D., Sowmya P.K. , Mini Priya R. (2012). Physico-chemical parameters of Karamana river water in Trivandrum district, Kerala, India International Journal of Environmental Sciences 2 (3):1417-1434.

Wolf $\mathbf{J}$, et al, (2013). An exploration of multi level modeling for estimating access to drinking water and sanitation. Journal of Water and Health, 11(1):64-77. 